\title{
ANALISA SEMIOTIKA SOSIAL PADA IKLAN CETAK AXE EFFECT - BODY SPRAY
}

\author{
Ratih Mahardika \\ Universitas Trilogi
}

\begin{abstract}
Abstrak: Iklan Axe selalu identik dengan kehadiran figur wanita dalam setiap iklannya. Padahal iklan Axe tidak ditargetkan untuk wanita. Produk Axe adalah produk kosmetik laki-laki. Kehadiran objek pakaian pada iklan Axe Effect - Body Spray versi cetak bertujuan menggantikan figur manusia secara halus. Dengan menggunakan analisis teks semiotika sosial yang difokuskan pada tata bahasa visual, paper berikut bertujuan untuk menguraikan tanda-tanda yang ada di dalam iklan Axe. Analisa menunjukkan bahwa stereotip wanita sebagai objek seksual laki-laki tidak berlaku ketika laki-laki menggunakan produk Axe.
\end{abstract}

Kata kunci: iklan cetak, Axe Effect, semiotika sosial, laki-laki, wanita

\begin{abstract}
Axe ads are always mostly identical with the presence of female figure in its advertisement. However, Axe ads are not targeted to women, Axe products are cosmetics for male. The presence of the clothes object on an advertisement of Axe Effect - Body Spray print version aims to replace the human figure smoothly. By using social semiotics text analysis focused on the visual grammar, the following paper aims to decipher the signs in the Axe ads. Analysis shows that the stereotype of women as sexual objects of men does not apply when a man uses Axe products.
\end{abstract}

Keywords: print ads, Axe Effect, social semiotics, men, women

Penulis adalah dosen program studi Desain Komunikasi Visual, Fakultas Industri Kreatif, Universitas Trilogi, email: ratihmahardika@universitas-trilogi.ac.id 


\section{PENDAHULUAN}

Produk Axe merupakan salah satu merek produk perawatan atau kosmetik laki-laki yang diperkirakan paling terkenal di dunia yang saat ini, dapat dengan mudah ditemui di 60 negara dan telah menjadi produk deodoran nomor satu di pasaran Eropa dan Amerika Latin. Sedangkan di Indonesia, produk Axe dikenal sebagai produk terkemuka dalam segmen deodoran (pengharum tubuh) pria. Iklan Axe di beberapa jenis media seolah-olah menunjukkan adanya efek pemakaian produk terhadap mental wanita sehingga menjadi tergila-gila kepada laki-laki yang memakai produk tersebut (Administrator Unilever, 2011). Iklan cetak Axe Effect Body Spray memiliki beberapa versi, diantaranya: versi confession, sharks, jeans, grave, wedding cake, dan bathutub (Administrator Responsiblemen, 2016). Dari beberapa versi tersebut, versi jeans terlihat menarik karena menggunakan objek pakaian sebagai pengganti figur manusia yang menunjukkan secara halus stereotip wanita sebagai objek seksual laki-laki.

\section{KAJIAN TEORI}

Setiap iklan media cetak pasti memiliki bahasanya masing-masing, baik yang bersifat verbal maupun non-verbal. Bahasa iklan dapat dilihat dari komponen Iklan berupa tanda yang ada di dalam iklan itu sendiri. Morrison (2007) menjelaskan bahwa komponen dasar iklan media cetak yang dapat disebut tanda terdiri dari: judul (headline), badan iklan (teks yang memuat pesan yang ditujukan kepada pembaca iklan, biasanya berupa slogan atau tagline), elemen visual (brand, logo, warna, foto, atau gambar ilustrasi produk yang diiklankan), dan layout yang digunakan. Dalam penelitian ini akan lebih menekankan pada elemen visual dan layout yang akan dianggap sebagai tanda.

Bahasa yang terdapat dalam iklan mengandung sebuah makna. Berdasarkan pendapat Kress dan van Leeuwen (1996), yang menjelaskan bahwa 
sebuah tanda (elemen visual serta layout) dalam komunikasi visual memiliki sebuah tata bahasa, yang mereka sebut sebagai tata bahasa visual (visual grammar). Dalam mencari sebuah makna sebuah desain visual, hal ini dapat diperoleh melalui makna representasional (representastional meaning), makna interaktif (interactive meaning), serta makna komposisi (composition meaning).

Representational meaning adalah melihat struktur naratif dan struktur konseptual. Interactive meaning menelaah tentang jarak, kontak antar tanda yang ada dalam teks, dan point of view. Sedangkan composition meaning melihat pada nilai informasi yang disampaikan, framing, dan ciri khas visual. Dari ketiga pemaknaan tersebut maka dapat diperoleh makna dari sebuah desain iklan.

\section{METODE PENELITIAN}

Penelitian ini dilakukan dengan mengunakan pendekatan kualitatif dengan menggunakan teori analisis teks semiotika sosial yang dilakukan dengan cara analisis deskriptif pada iklan cetak Axe Effect - Body Spray versi Jeans. Iklan ini dipilih karena menggunakan objek pakaian sebagai pengganti figur manusia. Analisis isi akan menguraikan semua tanda yang ada pada iklan tersebut. Sedangkan semiotika sosial yang digunakan lebih difokuskan pada tata bahasa visual (visual grammar).

\section{HASIL DAN DISKUSI: URAIAN MAKNA DALAM SISTEM TANDA}

\section{A. Representational meaning}

Penggambaran tanda-tanda dalam iklan ini bersifat diam, tidak dikonstruksi untuk merepresentasikan rangkaian peristiwa yang membentuk suatu cerita sehingga dapat terlihat langsung konsep dari makna-makna yang terkandung. Iklan cetak Axe ini termasuk dalam conceptual meaning, di dalam iklan Axe ini terdapat classification structure yang terlihat dari hubungan antar 
tanda, yaitu hubungan simbolistik celana jeans dan baju atasan wanita yang mengkonotasikan posisi subordinat wanita dan posisi superordinat laki-laki.

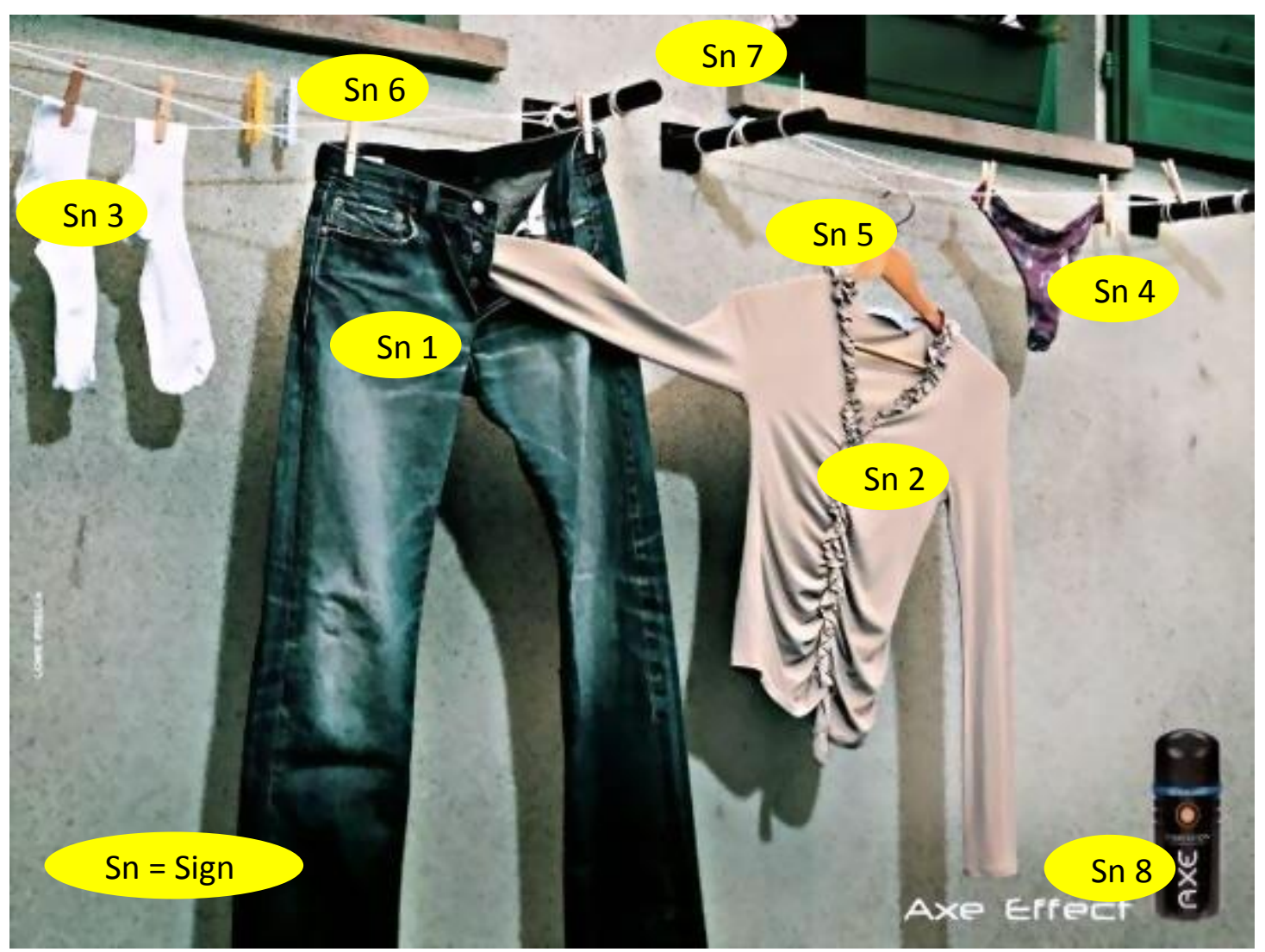

Gambar 1. Iklan cetak Axe dengan bagian tanda-tanda

Sumber: http://responsiblemen.files.wordpress.com/2008/12/axetc2.jpg

Selain itu, juga terdapat symbolic structure yaitu adanya hubungan antar tanda yang terlihat sangat mencolok (salient) antara tanda celana jeans dan baju bagian atas wanita, di mana kedua tanda tersebut seolah-olah menggambarkan sebuah gestur atau gerakan tubuh manusia yang menjadi pointing out the symbolic attribute to the viewer dalam iklan ini (Kress dan van Leeuwen, 1996, h. 79 dan 105). Karena semua tanda memiliki motivasi, maka tanda yang direpresentasikan melalui gambar menunjukkan bahwa iklan cetak yang menjadi 
salah satu bentuk dari desain komunikasi visual dihasilkan dari rasionalitas, dilandasi pengetahuan, bersifat logis, dan pragmatis (Widagdo, 1993, h.31). Berikut penjelasan makna dari setiap tanda:

\section{Sn 1: Celana Jeans}

Celana jeans yang digambarkan menunjukkan jenis celana jeans yang biasanya dipakai oleh laki-laki, terlihat dari model potongan celana men wide leg jeans yang memiliki potongan lebar dari pantat sampai mata kaki dan tidak menunjukkan siluet tubuh jika dipakai. Model tersebut diperuntukkan untuk lakilaki yang bertubuh atletis dan besar (Indunkz, 2010). Celana jeans identik dengan pemakai laki-laki karena berdasarkan sejarah, celana jeans dibuat di Genoa, Italia tahun 1560-an yang dipakai oleh angkatan laut dan di Amerika Serikat dipopulerkan oleh Levi Straus tahun 1850-an yang diproduksi untuk dipakai para penambang emas (Subakti, 2006). Menurut Davis (1992) dalam Barnard (2009, h.181) celana jeans mengekspresikan kebebasan yang berarti menolak adanya perbedaan kelas di masyarakat dan kebebasan dalam bergerak atau beraktivitas. Celana jeans dalam iklan Axe ini merupakan simbol perwakilan figur laki-laki dan mengkonotasikan sasaran konsumen yang dituju yaitu laki-laki dari semua kelas dengan berbagai profesi pekerjaan.

\section{Sn 2: Baju Bagian Atas Wanita (Blouse)}

Kata blouse umumnya menuju kepada pakaian wanita, terbuat dari bahan yang ringan seperti: katun, sutra, atau spandex, dibuat dengan atau tanpa kerah dan lengan. Umumnya blouse dijahit sebagai atasan dengan model yang sederhana, yang mempunyai detail-detail yang lebih feminism seperti lipit-lipit pada bagian depan, dasi, pita pada leher, embroidery atau dengan kancing-kancing yang dekoratif (Laurentia, 2010). Blouse yang digambarkan dalam iklan Axe ini merupakan blouse yang berbahan ringan yang seakan-akan jika dipakai oleh 
wanita akan membentuk siluet tubuh, yang jika dilihat oleh orang lain akan menimbulkan gambaran atau bayangan terhadap bentuk asli tubuh wanita yang memakai blouse tersebut.

Menurut Flugel (1950) dalam Barnard (2009, h.99) adanya pandangan yang mencolok dari the Psychology of Clothes bahwa terdapat sebuah kenikmatan atau kesenangan yang dirasakan banyak orang yang ditimbulkan oleh pakaian yang membentuk siluet tubuh yang mengkonotasikan ketelanjangan. Selain itu, menurut Berger (1972) dalam Barnard (2009, h.99) kenikmatan atau kesenangan yang ditimbulkan oleh pakaian melalui padangan bergantung pada gender orang yang melihat. Hal tersebut juga didukung oleh Danesi (2010) yang mengangangap bahwa konsep laki-laki sebagai pihak yang "melihat" dan perempuan sebagai "yang dilihat" adalah konsep yang diwariskan oleh tradisi budaya barat.

Penggunaan model blouse tersebut mengonotasikan tuntutan laki-laki terhadap tubuh wanita yang harus terlihat menarik secara fisik atau memiliki bentuk tubuh ideal, laki-laki cenderung menyukai wanita dengan bentuk tubuh yang padat dan berisi sehingga wanita tersebut akan terlihat menarik jika menggunakan blouse yang ketat (Zamroni, 2009). Blouse tersebut merupakan simbol perwakilan figur wanita, diperkuat dengan warna blouse yaitu pink yang menjadi simbol dari gender perempuan yang mengkonotasikan cinta, kasih sayang, kelembutan, dan feminine (Anna, 2008). Penggunaan baju atasan wanita dalam iklan Axe ini merupakan konotasi wanita sebagai korban dari efek penggunaan produk Axe oleh laki-laki di mana laki-laki selalu tergoda untuk menjadikan wanita sebagai objek seksual mereka, memperkuat konotasi wanita sebagai posisi subordinat. 


\section{Sn 3: Kaos Kaki}

Ikon kaos kaki yang digambarkan merupakan jenis kaos kaki untuk laki-laki yang berwarna putih diperkuat dengan penempatan ikon kaos kaki berada di samping kiri ikon celana jeans yang mengkonotasikan laki-laki. Kaos kaki umumnya dipakai oleh para pekerja, terutama laki-laki dengan beragam jenis sepatu mulai dari yang bermerek sampai yang pasaran (Poespo, 2009, h.11). Ikon kaos kaki yang ada dalam iklan merupakan jenis kaos kaki berwarna putih yang lebih sesuai untuk kegiatan olah raga atau kegiatan yang dapat mengeluarkan keringat lebih (Rhesa, 2015). Selain itu, kaos kaki putih lebih identik dengan penggunaan ikon kaos kaki berwarna putih merupakan konotasi status sosial dan pekerjaan dari segmen lakilaki yang disasar oleh iklan ini. Status sosial dan pekerjaan yang disasar adalah laki-laki yang relatif masih muda, bukan pekerja kantoran, dinamis, sporty, dan yang berasal dari segmen pecinta gaya kasual.

\section{Sn 4: Celana Dalam Wanita}

Kata celana dalam mengidentifikasikan bagian terintim dari setiap orang. Ikon celana dalam wanita dalam iklan Axe ini merupakan simbol seksualitas yang ditujukan kepada wanita diperkuat dengan penempatan berada di samping kanan ikon baju bagian atas wanita (blouse) warna pink. Celana dalam wanita merupakan simbol dari keseksian tubuh wanita. Model celana dalam wanita yang digunakan dalam iklan Axe ini merupakan celana dalam model $g$-string atau thongs yang tidak menutupi bagian pantat secara penuh (Poespo, 2009, h.41).

Model celana dalam ini untuk mengonotasikan kesan seksi sipemakai. Warna celana dalam wanita pada iklan Axe ini adalah warna hitam yang merupakan warna paling gelap untuk pakaian dalam wanita yang mengkonotasikan penampilan yang elegan dan seksi (Audsley, 1928, h.89). Penggunaan ikon celana dalam wanita menunjukkan adanya pergeseran teori 
zona tubuh wanita yang dianggap erotis yaitu pada bagian bawah tubuh wanita. Hal tersebut oleh Laver (1969) dalam Barnard (2009, h.81) disebut bahwa pakaian wanita diatur oleh prinsip godaan sehingga mengonotasikan daya tarik seksual kepada lawan jenisnya. Dengan ikon celana dalam wanita menjadikan suasana sensual dalam iklan semakin kuat.

\section{Sn 5: Gantungan Baju (hanger)}

Ikon hanger yang terbuat dari kayu dengan pengait besi disebut wooden hanger, berfungsi sebagai tanda pendukung ikon baju atasan wanita (blouse) pink. Hanger merupakan alat perlengkapan pakaian yang mutlak ada di dalam lemari dan juga digunakan untuk menjemur pakaian seperti yang digambarkan dalam iklan Axe ini. Hanger yang biasanya dipakai untuk menjemur pakaian adalah hanger berbahan plastik atau sintetik, akan tetapi yang digunakan dalam iklan ini adalah wooden hanger yang sebenarnya peruntukkannya sebagai penambah penampilan display toko pakaian, butik, gantungan baju di lemari hotel, apartemen, guest house, atau juga dapat digunakan untuk mempercantik interior rumah (Administrator Lunetta, 2010). Ikon wooden hanger tersebut memperkuat ikon pink blouse yang mengkonotasikan penampilan wanita yang harus terlihat menarik di mata laki-laki. Selain itu, dapat juga menunjukkan kelas sosial wanita yang berasal dari kelas menengah ke atas.

\section{Sn 6: Tali dan Jepitan Baju}

Tali dalam iklan digambarkan sebagai tempat untuk menggantung celana jeans, kaos kaki, blouse, dan celana dalam. Ikon tali berfungsi untuk mengasosiasikan jemuran baju diperkuat dengan ikon jepitan baju. Tali jemuran tidak digambarkan dalam satu sambungan tali. Terlihat tanda celana jeans dan kaos kaki serta tanda pink blouse dan celana dalam berada pada tali jemuran yang berbeda. Tali mengkonotasikan adanya sangkut-paut, hubungan, bersambungan, 
dan dalam satu ikatan (Adminstrator Artikata, 2011). Dengan penggambaran tersebut menandakan bahwa figur manusia (laki-laki dan perempuan) yang dikonotasikan dengan pakaian, tidak memiliki atau terikat dalam suatu hubungan. Hal tersebut menunjukkan bahwa sasaran konsumen produk Axe merupakan lakilaki yang tidak terikat dalam sebuah hubungan atau dalam kondisi sendiri-tidak berpasangan (single) yang ingin mendapatkan pasangan dengan cara menarik perhatian wanita yang juga tidak dalam kondisi berpasangan.

\section{Sn 7: Background Dinding dan jendela}

Penggunaan background dinding dan jendela yang terlihat terbuka merupakan ikon dari bagian belakang sebuah bangunan. Pemakaian ikon tersebut memperkuat ikon tali jemuran dan jepitan baju yang biasanya ditempatkan di bagian belakang rumah. Ikon-ikon tersebut menjadi tanda metonimi dari sebuah bangunan rumah yang mengkonotasikan sebuah tempat di mana biasanya terjadi pembagian posisi laki-laki sebagai superordinat dan wanita sebagai subordinat. Menurut Bhasin (1996) dalam Sunarto (2009, h.38) menyebutkan adanya suatu pandangan tentang kekuasaan laki-laki atas wanita (superordinat atas subordinat) yang terjadi dalam lingkungan terkecil yaitu rumah.

\section{Sn 8: Teks "Axe Effect" dan Gambar Produk Axe}

Keberadaan ikon produk Axe dengan teks "Axe Effect" bertujuan untuk memperjelas tujuan iklan dan membangun memori audiens akan iklan-iklan Axe lainnya di mana teks tersebut menggambarkan dampak dari pengharum tubuh tersebut terhadap mental wanita. 


\section{B. Interactive meaning}

\section{Contact}

Adanya kontak antar tanda dalam iklan ini yang terlihat mencolok dari ikon celana jeans dan pink blouse yaitu menyangkutnya bagian lengan blouse pada bagian resleting celana jeans yang terbuka. Lengan blouse dikonotasikan sebagai lengan tangan wanita sedangkan resleting yang terbuka mengkonotasikan bagian organ vital atau intim laki-laki. Penggambaran lengan blouse yang seolah-olah menyangkut pada resleting yang terbuka menunjukkan unsur seksualitas di mana akibat penggunaan produk $A x e$, wanita digambarkan memiliki ketertarikan seksual yang lebih terhadap laki-laki yang memakai produk Axe dan rela mengabdikan dirinya sebagai objek seksualitas.

Sesuai dengan Heslin (tanpa tahun) dalam Mulyana (2004, h.336) yang menyatakan salah satu bentuk komunikasi nonverbal adalah dalam bentuk sentuhan, salah satunya yang menunjukkan keterikatan emosional atau ketertarikan dikategorikan dalam sentuhan cinta-keintiman atau rangsangan seksual. Kemudian kontak antar tanda juga terlihat dari ikon kaos kaki dipasangkan dengan ikon celana jeans dan ikon celana dalam wanita dipasangkan dengan ikon pink blouse, di mana kondisi pemasangan ikon-ikon tersebut mengkonotasikan suasana yang sensual karena penggunaan pakaian sebagai pengganti figur individu ditampilkan secara tidak lengkap. Hal tersebut menimbulkan kontak emosional pada penglihat (audience), terutama audiens laki-laki terhadap iklan, yaitu timbulnya hasrat dan fantasi seksual untuk membuat wanita tergila-gila pada mereka sehingga mendorong mereka untuk memakai produk Axe. Akan tetapi dalam iklan ini tidak terlihat adanya kontak mata secara langsung antara penglihat dengan tanda-tanda yang terdapat dalam iklan dikarenakan figur manusia digantikan oleh pakaian. 


\section{Distance}

Iklan Axe ini mengkonotasikan adanya jarak fisik yang terbentuk antara laki-laki dan wanita dengan menggunakan ikon celana jeans dan ikon pink blouse. Menurut ilmu proksemik oleh Edward T. Hall (1996) dalam Mulyana (2004, h.359), jarak fisik yang terbentuk dari ikon celana jeans dan ikon pink blouse termasuk jarak intim dimana jarak sosial manusia yang ditentukan berjarak antara $0 \mathrm{~cm}$ sampai dengan $45 \mathrm{~cm}$, yang dapat merepresentasikan aktivitas berpelukan, berpegangan, atau berbisik dengan kondisi jarak sangat dekat. Jarak intim yang digambarkan melalui kontak antara ikon celana jeans dan ikon pink blouse juga mengkonotasikan jarak emosional hubungan antar manusia yang sangat dekat.

\section{Point of View}

Penggambaran gestur bagian lengan pink blouse (dikonotasikan lengan tangan wanita) yang tersangkut pada resleting celana jeans yang terbuka (dikonotasikan sebagai bagian organ vital laki-laki) terlihat mencolok dan memperkuat konstruksi seksual dalam iklan sehingga menjadi point of view dari iklan cetak Axe ini. Menurut Birdwhistel (1952 dan 1970) dalam Danesi (2010, h.74-77) menjelaskan bahwa konotasi gestur lengan wanita merupakan kode kinesis mengetarai persepsi orang dengan menunjuk bagian tubuh atau zona erotis yang mengejewantahkan naluri untuk bereproduksi, di mana kode-kode tersebut dibentuk oleh pendapat manusia mengenai gender dan percintaan. Selain itu juga dikarenakan posisi kedua tanda tersebut yang berada di tengah iklan, menjadikan kedua tanda tersebut menguasai komposisi bidang iklan. 


\section{Compositional meaning:}

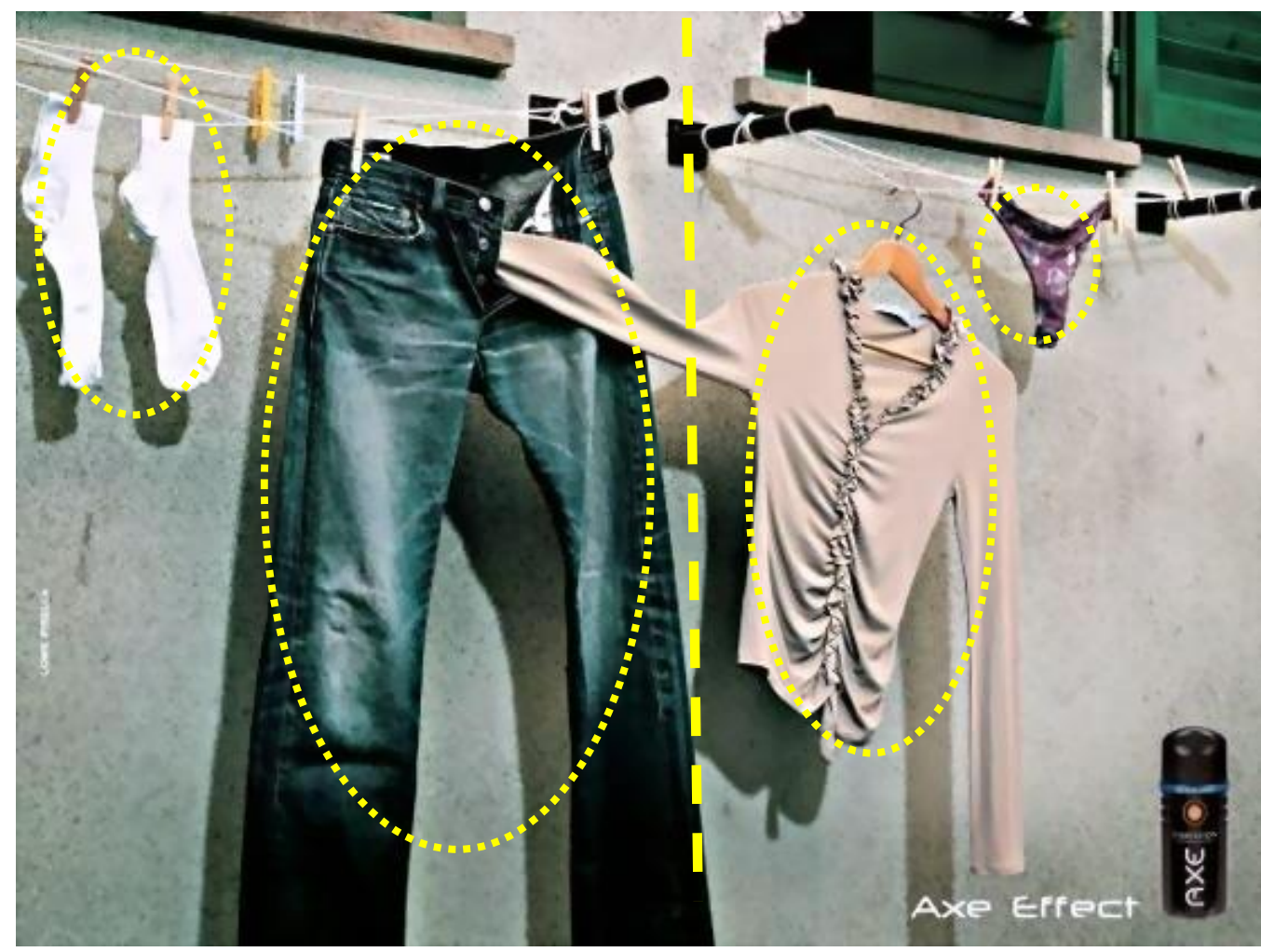

Gambar 2. Iklan Axe dengan pembagian area tanda

Sumber: http://responsiblemen.files.wordpress.com/2008/12/axetc2.jpg

\section{Information Value}

Penempatan tanda-tanda dalam iklan Axe juga memiliki makna tersendiri. Ikon celana jeans di tempatkan di sisi kanan dari ikon pink blouse (jika dilihat dari sudut pandang audiens) yang kemudian diperkuat dengan ikon kaos kaki sebagai penguatan konotasi laki-laki dari ikon celana jeans dan ikon celana dalam wanita untuk memperkuat konotasi wanita dari ikon pink blouse. Ikon-ikon tersebut mengonotasikan sebagai laki-laki yang dianggap lebih superior daripada wanita (posisi laki-laki yang superordinat atas wanita yang subordinat).

Posisi ikon-ikon tersebut berkaitan dengan etika kehidupan sehari-hari yang merupakan hasil pemikiran jaman patriarki. Posisi kanan dianggap lebih baik 
dan lebih berkuasa dari pada posisi kiri, sehingga mengkonotasikan wanita sebagai posisi yang termajinalkan, subordinat, menjadi korban kekerasan laki-laki yang selalu berada dibawah kendali laki-laki dan merupakan wujud dari dominasi lakilaki (Murniati, 2004, h.xxiii). Ikon celana jeans dan ikon pink blouse diletakkan di posisi sentral sebagai pesan utama dari iklan ini, yaitu pesan seksualitas dengan menggambarkan wanita yang terkena efek dari produk Axe yang merupakan konstruksi pemikiran laki-laki. Sedangkan, ikon produk Axe dan teks "Axe Effect" diletakkan pada sudut kanan bawah sebagai maksud untuk memperjelas tujuan iklan. Penempatan tanda tali jemuran, jepitan jemuran, dinding dan jendela terbuka dibagian belakang sebagai background dan sebagai pendukung tandatanda utama.

\section{Silence}

Keseluruhan komposisi tanda menggunakan beberapa macam pakaian sebagai tanda visual pada iklan cetak Axe, yang bertujuan untuk menggantikan figur manusia (individu). Keempat tanda yang menggunakan pakaian menjadikan iklan ini terlihat menarik, dan yang sangat terlihat mencolok dari komposisi tanda ini adalah ikon celana jeans dan ikon pink blouse. Karena penempatan yang tepat berada di tengah bidang iklan, serta ukuran ikon yang terlihat lebih besar daripada tanda-tanda yang lain, dan diperkuat dengan konotasi gestur yang digambarkan oleh kedua tanda tersebut. Sedangkan ikon kaos kaki dan ikon celana dalam sebagai tanda pendukung (participant) yang berfungsi untuk mempertegas konstruksi dalam iklan yang terlihat dari penempatannya serta ukurannya yang lebih kecil dari tanda-tanda utama.

\section{Modality}

Dengan adanya iklan Axe ini, memberikan gambaran realitas tentang superioritas laki-laki terhadap wanita. Laki-laki mengontrol wanita dan 
menjadikan wanita sebagai obyek seksual mereka. Menurut Sunarto (2009, h.173) kekuasaan laki-laki mengontrol mental wanita menyimbolkan cara kaum laki-laki mengobyektifkan kaum wanita. Sesuai dengan maksud dari iklan Axe yaitu mengontrol mental wanita agar menjadi tergila-gila terhadap laki-laki yang memakai produk Axe. Secara keseluruhan makna yang terkandung dalam iklan Axe ini merupakan realitas dari sebuah konsep atau cara pencarian pasangan hidup yang diinginkan laki-laki terhadap wanita.

\section{KESIMPULAN}

Secara garis besar, iklan Axe ini menggambarkan hubungan antara laki-laki dengan perempuan dengan membentuk persepsi tentang bagaimana peran lakilaki terhadap wanita dalam hal seksual. Dalam iklan jelas terlihat bahwa karakter perempuan yang lebih agresif atau lebih memiliki hasrat terhadap laki-laki. Hal ini merupakan efek yang diharapkan oleh iklan Axe itu sendiri yaitu ketika seorang laki-laki menggunakan produk Axe maka laki-laki tersebut akan mendapatkan wanita yang sangat tergila-gila terhadap laki-laki tersebut. Akan tetapi iklan Axe ini, merupakan iklan Axe yang 'sopan' karena secara keseluruhan dari versi-versi iklan Axe lainnya, hanya iklan ini saja yang menggantikan figur manusia (laki-laki dan wanita) dengan objek benda yaitu pakaian.

Iklan Axe Effect - Body Spray ini menunjukkan bahwa kehadiran figur manusia yang digantikan oleh objek lain yang lebih sederhana (pakaian) dapat menjadi salah satu alternatif strategi komunikasi visual sebuah desain iklan; terutama pada iklan produk orang dewasa yang memuat pesan tentang bagaimana hubungan antara laki-laki dan wanita. 


\section{DAFTAR PUSTAKA}

Audsley, George Ashdown. 1928. Color Harmony in Dress. New York: Robert M. Mc Bride \& Company.

Barnard, Malcolm. 2009. Fashion sebagai Komunikasi. Bandung: Jalasutra.

Danesi, Marchel. 2010. Pesan, Tanda, dan Makna. Bandung: Jalasutra.

Kress, Gunther dan van Leeuwen, Theo. 1996. Reading Images: The Grammar of Visual Design. London: Routledge.

Morrison. 2007. Emotional Inteligence: Emotional and social work: Context, characteristic, complications and contribution. British Journal of Social Work.

Mulyana, Deddy. 2004. Ilmu Komunikasi: Suatu Pengantar. Bandung: PT Remaja Rosda Karya.

Murniati, A. Nunuk. 2004. Getar Gender: Perempuan Indonesia dalam Perspektif Agama, Budaya, dan Keluarga. Magelang: Indonesia Tera.

Poespo, Goet. 2009. A to Z Istilah Fashion. Jakarta: PT Gramedia Pustaka Utama.

Sunarto, 2009. Televisi, Kekerasan, dan Perempuan. Jakarta: PT Kompas Media Nusantara.

Widagdo, 1993. Desain Teori dan Praktek. Seni Jurnal Pengetahuan dan Penciptaan Seni. BP ISI Yogyakarta III/03.

\section{Sumber Lain}

Administrator Lunetta Online Shop Furnitur dan Dekorasi, 2010. Almari Pakaian dengan Cermin: Cara Mensiasati Ruang Tidur Berukuran Kecil. Diakses 
dari <http://lunetta.kayumanis.asia/category/ruang-tidur/> (tanggal 07 Mei 2011)

Administrator Unilever, 2011. Axe. Diakses dari <http://www.unilever.co.id/id/ brands/personalcarebrands/axe/> (tanggal 07 Mei 2011)

Anna, Lusia Kus. 2008. Psikologi dan Arti Warna. Diakses dari <http://nasional.kompas.com/read/2008/10/09/15551015/psikologi.dan.arti.wa rna> (tanggal 07 Mei 2011)

Administrator Artikata. 2011. Diakses dari http://www.artikata.com/arti-379997tali-bertali.html (tanggal 07 Mei 2011)

Administrator Responsiblemen. 2016. Diakses dari <https://responsiblemen. wordpress.com/> (tanggal 19 Februari 2016)

Indunkz, 2010. Delapan Macam Celana Jeans dan Tips Mengenakannya. Diakses dari http://ntunkz.wordpress.com/2010/03/09/8-macam-celana-jeanstips-mengenakannya/ (tanggal 07 Mei 2011)

Laurentia, Maria. 2010. Macam-macam Definisi Jenis Pakaian. Diakses dari http://maria-laurentia.blogspot.com/2010/08/macam-macam-definisijenis-pakaian.html (tanggal 07 Mei 2011)

Rhesa. 2015. Men's Guide: Panduan Kaos Kaki Pria. Diakses dari http://malezones.com/artikel/mens-guide-panduan-kaos-kaki-pria.html (tanggal 10 Februari 2015)

Subakti, Ricky B. 2006. Sejarah Jeans. Diakses dari <http://rsubakti.blog.friendster .com/2006/09/sejarah-jeans/>_(tanggal 07 Mei 2011) 
Zamroni, Muhammad. 2009. Bentuk Tubuh Wanita Ideal. Diakses dari http://muhammad.zamroni.net/bentuk-tubuh-wanita-ideal.html (tanggal 07 Mei 2011)

\section{Gambar:}

Diakses dari: http://responsiblemen.files.wordpress.com/2008/12/axetc2.jpg Tanggal 06 Mei 2011 